$1 F-08$

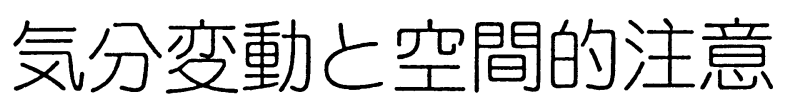

\title{
○岩崎祥一（福島医大·心理学）・片平清昭（福島医大·実験動物） Mood Swing and Spatial Attention
}

\author{
Syoichi Iwasaki (Fukushima Med. Col, Psychology) \\ Kiyoaki Katahira (Fukushima Med. Col., Experimental Animal Lab.)
}

\section{1.はじめに}

運転行動においては、注意のコントロール の適否が重大な結果につながる。我々は、気 分の変動が運転行動にどのように影響するか に主眼をおいた研究を行ってきたが、ここで は、気分変動が注意のコントロール能力にど のように影響するかを、薬物（スコポラ ミン）を用いて気分の変動を誘発することで 調べた。

\section{2. 方法}

課題：被験者は、手掓刺激により注意を手掛 提示部位にコントロールし、凝視点の左右の いずれかの位置にターゲットを検出したら、 その位置に対応するキイをなるべく早く押す ように要請された。その際に要した反応時間 を测定した。

刺激：コンピュータの画面上の凝視点を挟ん だ視角にして $3^{\circ}$ の位置に、田の字をなす 2 個の図形とこの図形を目む点線で描かれた枠 とを、凝視点の提示と同時に提示した。この 図形の一部が消失し、十字形となったものが ターゲット図形とされた。手掛刺激は、朹の 辉度增㞦により行った。

手掛刺激の条件：手操刺激は、Posnerの方法 に従い、以下の 3 つの条件が設けられた： 1. valid条件：手措刺濒の示す部位にターゲッ トが提示される、2. invalid条作：手撕刺激の 提示視野と反対侧の祝野にターゲットが提示 される、3.both条件：手挂刺激は、両視野と もに提示され、どちらにターゲットが出現す るかは、被験者には分からず、ターゲットの 出現のタイミングのみが他の条件と同一にし てある。
手掛刺激が提示されてからターゲットが提 示されるまでの時間 (cue lead time) は、50 msecと150 msecの 2 種であった。

薬物投与及び気分の評定: 気分を操作する手 段として臭化水素酸スコポラミン $(0.5 \mathrm{mg})$ を 用いた。スコポラミンは、記憶や注意の働き と関係が深いとされるアセチルコリンの拮抗 薬で、脳内アセチルコリンを低下させること が知られている。

被験者は、二重盲検法により、スコポラ ミン $1 \mathrm{~m} 1$ あいい同量の生理食塩水を皮下注 射により投与された。投与後少なくとも 30 分 が経過してから実験を開始した。

投与前後で、気分がどう変化したかを評価 する目的で、最大を100とした直線に現在の 気分をアナログでマークする評定票を用い た。評定した気分は、楽しさ、イライラ、気 分の落ち込み、意欲、不安の 5 種類であっ た。

被験者：大学生 5 名。

\section{3. 結果}

図1に示したように、生理食塩水の投与時 と比し、スコポラミンは気分の落ち込みや意 欲の低下をもたらした。

図 2 には、反応時間に反映された注意の効果 を示した。個々の要因の結果は以下の通り。

手掛刺激の効果：従来から知られているよ うに、手撕かり刺激が有效な場合には反応時 閌は、both条件と比べて減少し、逆に手祘か り刬激が門效であった場合には增加した（手 撕かり刺激の效果は、左右の視野ともに分散 分析により $1 \%$ levelで有意）。 
cue lead timeの効果 : cue lead timeが50 $\mathrm{msec}$ の侍に比べで150 msecの将には注意の效 果が大きかった（左視野は1\% level、右視野 は5\% level）。

薬物の効果：スコポラミンの投与は、反応 洔間を全体として遅らせた（左右の視野とも に5\% leve1）。

注意の效果を注意を逆の視野に向けた向け たための損失（invalid条件の反応侍間一 both条件の反応時間）と注意をターゲットの 位置に向けたことによる利得（both条件一 valid条件）に分け、それぞれ、cue lead time、薬物、視野の 3 つの要因の效果を分散 分析により検討した。その結果、利得には上 記の要因の影響は見られなかったが、損失 は、cue lead time ( $1 \%$ level) と視野 ( $5 \%$ leve1）が有意となった（図 3）。

\section{4. 考察}

1. 意欲の低下した状態では、反応時間は全 体として遷延するが、注意のコントロールと いう観点からは、特に影響はない。

2. 左視野に比べ右視野では注意が不適切な 場所に向けられた時に、必要な場所に向け直 すのにより多くの時間を要した。これは、注 意のdisengagementの視野差と言える。

2 の結果は、自動車の通行区分（右侧通行 か左侧通行か) と安全という锶点から興味深 い知見と考えられる。日本のような左側通行 では、運転者の注意が視野の左侧つまり歩道 の侧に向いた場合には、その逆の方向に注意 を向き変えるのに、相対的に余計な時間を要 する。これは、具体的には運枟者が対向車に 注意を払うのが遅くなるという結果をもたら す。これに対し、欧米のような右侧通行で は、対向車に注意を奪われると、歩道側への 注意の枟換に余分の時開がかかることにな る。つまり、不適切な注意のコントロールが 事故に結びついているとすると、右侧通行と 左侧通行では、事故の性質に差が出てもおか しくない（日本では対向車との衝突、欧米で は歩行者や自転車との事故）ことになる。

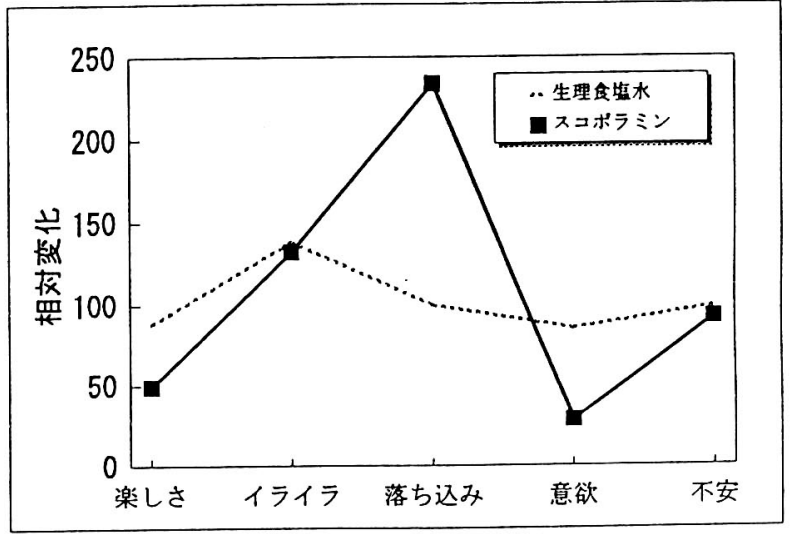

図 $1 ：$ スコポラミン投与により誘発された気分変動

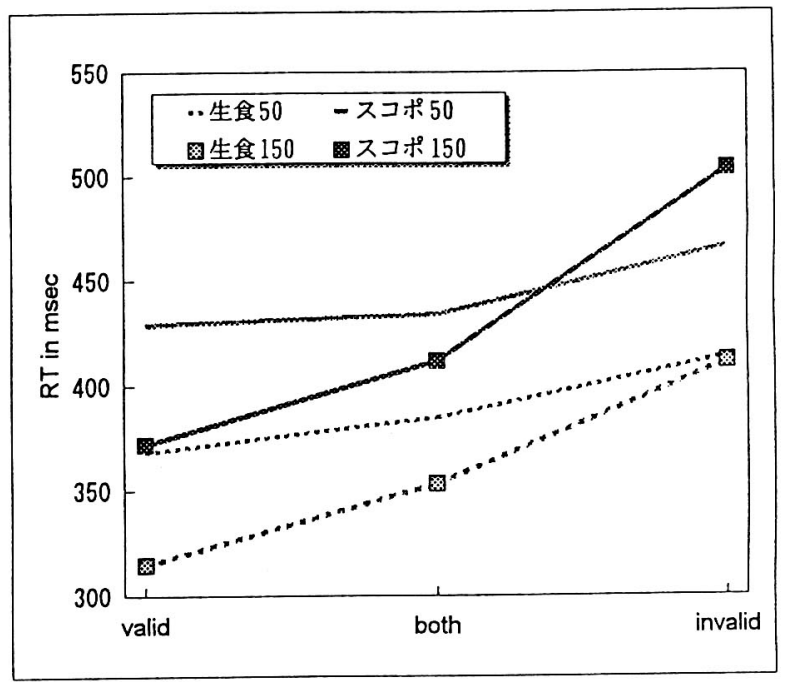

図 2 : スコポラミンの空間的注意への影響（右視野）

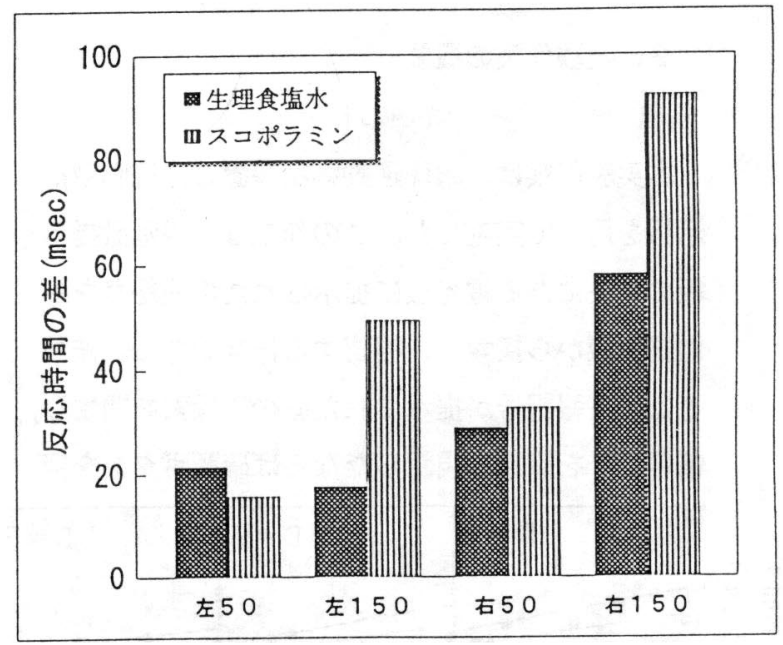

図 3：注意の損失 